\title{
三題噺 : SGML·コンテンツ·大学ランキング
}

\section{SGML, Digital Contents and University Rankings: A Short Story with Three Topics}

\author{
根岸正光 \\ Masamitsu NEGISHI
}

国立情報学研究所

National Institute of Informatics

干101-8430 東京都千代田区一ツ橋2-1-2

E-mail: negishi@nii.ac.jp

情報知識学会創立30周年記念号への寄稿というので、改めて「情報知識学会誌」への筆者の論 稿、記事の掲載履歴を調べてみたら、28件程あった(「研究報告会講演論文集」を含む。1993年の 第1回年次大会から2003年の第11回大会まで、大会予稿集は学会誌とは別に「研究報告会講演論 文集」として刊行され、その後「情報知識学会誌」の特集号に組み入れられて現在に至る）。論稿等 の主題はいろいろだが、ここではSGML、コンテンツ、大学ランキングといら三題噺仕立てで回顧を試 みたい。

\section{SGML}

「情報知識学会誌」における筆者の論稿記 事（共著を含む）28件中の最初のものは、 1997年の第1回SGML研修フォーラムの予稿 「SGMLと電子文書の現況と将来」である（6 巻2号、SGML研修フォーラム特別号)。我々 は電子化文書の将来的普及進展に期待し て、早くからSGMLに注目してきたところで、 1990年の情報知識学会誌創刊号は凸版印 刷の協力によりSGMLを用いて発刊された。 これはわが国で初めてのSGML実用の試み であったと思う。

しかし、SGMLは、米軍用のマニュアルな どにおいて、頻繁な更新を確実に管理する ための文書管理システムの一環として発
案されたもので、こうした特殊な利用環境 向きと考えられ、一般への普及は進まなか ったが、1995年頃から、電子化文書の方式 として民間での関心が高まってきた。そこ で1997年、情報知識学会では「SGML研修フ オーラム」と題して第1回のセミナーを開 催したところ、他に類似のものがなかった せいか、2日間で2万円という参加料だった が、関連企業から多数の参加者あり、これ 以後数年間、このフォーラムは学会の「収 益」事業となって学会財政の充実に貢献し た。

折からWWWがSGMLの簡易版であるHTMLを 採用したことや、より実用的なXMLが提案 されたこともあり、第2回からは「SGML/XML 
研修フォーラム」とし、参加費も2.8万円 にしたが毎年大盛況であったのが思い出 される。このフォーラムは2004年の第9回 まで続いたが、さすがに賞味期限切れか 追々不入りとなり、2005年の第10回からは、 幅広いテーマを扱うべく「情報知識学フォ 一ラム」と改名して、現在に至っているの である。

\section{2 コンテンツ}

筆者のこの業界での振り出しは、学術文 献抄録データベースのためのオンライン 検索システムの開発で、つまりデータベー ス屋である。文献抄録誌は戦前からあるが、 その編集をコンピュータ化し、製品も印刷 物ではなく、コンピュータ・ファイルの形 で頒布する。これがデータベースである。 その後、コンピュータの高性能化に合わせ て、元々の論文誌自体の編集もコンピュー タ化されるようになってきた。その製品は 印刷版雑誌だけでなく、コンピュータ・フ アイル版もできる。この種のものを、抄録 データベースに対して全文データベース といった。上記のSGMLもこうした流れの上 での話題である。

全文データベースが発展すれば、図書館 では、印刷版の雑誌に代わって、コンピュ 一タ版の方を導入して、次第に電子図書館 になって行くであろう。1999年の第7回年 次大会の筆者の演題は「デジタル・コンテ ンツ・サービスの動向と情報学」というの で、デジタルだのコンテンツだのがはやり 言葉になった当時の時勢が分かる。これか らはデータではなく、コンテンツだという わけである。ほぼ10年後の 2011 年、年初の 巻頭言を「電子書籍 2 年」（21巻1号） と題 しているが、こうした趨勢は今に続いてい
るであろう。もつとも昨今は、ビッグ・デ ータだの、データ・サイエンティストだの と、AIがらみで「データ」の復権もめざま しいようなのが面白い。

\section{3 大学ランキング}

学術文献関連データベースでは、抄録や 全文とは別に、ガーフィールドの発案にか かる引用索引データベースがある。これも 当初の手作業編集の印刷版からデータベ ースヘと進化したもので、現在の”Web of Science"に至る。その二次加工品で論文別 の引用数統計を収めたデータベースを 2000年に入手して、わが国の大学別の被引 用度のランキングを計測した。何分本邦初 の大学の研究力の客観評価なので、差し障 りの向きから余計な真似をするなと難癖 を付けられてはしゃくだから公表媒体を 慎重に検討して、日本学術振興会発行の 「学術月報」（53巻 3 号）に結果を掲載し た。

折から、朝日新聞発行の「大学ランキン グ」誌がこれに注目して、ランキング結果 採録の申し入れがあり、2001年発刊の同誌 「2002年版」に寄稿した。以後「大学ラン キング」誌からは毎年更新統計寄稿の申し 入れがあり、データベースの版元、クラリ ベイト・アナリティクス社の協力を得て、 毎年統計を出すようになり、今 2018 年4月 刊行の「大学ランキング2019年版」まで、 実に18年間にわたる連載でライフワーク 風になっている。

情報知識学会には、引用統計以前にも、 1997年から文献抄録データベースを用い た論文数の国別比較統計の調査結果を発 表したが、2000年以降、引用統計関係の大 会発表を行っている。この間、論文当たり 
の平均引用数という単純統計から始めて、 東大以外が上位進出するような「皆様に喜 ばれる」指標の計算法の開発に心掛けて、 2004年の国立大学法人化以降には、業績評 価のための引用統計指標の提案などを年 次大会で発表した（20巻 2 号他）。

国立大学の法人化以降、大学、研究機関 の研究資金は、評価に基づく選択と集中と いう、苛烈な政策下におかれている。おか げで、その研究評価のためのビブリオメト リックスはいよいよ盛んになり、これは今 や情報知識学会の重要な研究テーマにな つて、論文投稿も多いのはいかにも皮肉な 感じではある。

\section{4 間抜け落ち}

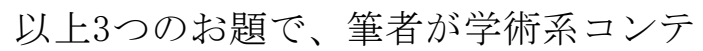
ンツ関連の研究開発に関わっていたら、な りゆきで研究評価という大それた領域に 足を踏み入れてしまった経緯をたどって みた。そこで、現下の形勢を見渡しつつ、 情報知識学会の将来に思いを致して一言 を労して、何とか落ちにつなげたい。

競争的資金による選択と集中を標榜す る昨今の科学技術政策は、学術研究振興政 策ではなく、経済成長のためのイノベーシ ヨンを何としても必中で創出したいと懸 命の経済政策、研究開発投資政策である。 選択と集中はハイリスク・ハイリターンの 投資話と同様の無理筋で、圧倒的多数の落 選者のみならずノ一ベル賞の先生までも 批判しているが、もはや簡単には止められ まい。してみると研究評価のビブリオメト リックスも情報知識学会の重要分野とし てしばらく安泰であろう。はやりのAI技術 の適用による的中率の向上が今後特に有 望と思われる。
一方、競争的資金により若手研究者の非 正規雇用が常態化して批判も強いが、政策 的ににわかに止められまい。また少子化に よる大学の斜陽産業化も深刻だから、大学 研究者は劣悪悲惨な職種とみなされて、若 者のなり手が消え失せてゆくのではない か。これすなわちアカデミア全体の地盤沈 下、液状化に他ならず、その一角にある学 会の足元も危うくなりつつあると憂慮せ ざるを得ない。

という次第で、話が辛気臭くなって気の 利いた落ちが付かず、この三題噺はとんだ 失敗作になってしまったが、高齢者の世迷 い言とご容赦願おう。

\section{謝辞}

本稿をまとめるに当たって、学会HPの「刊 行物アーカイブ」にはすっかりお世話にな った。2008年の20周年記念事業では前学会 誌編集委員長、国沢隆先生の努力により学 会誌アーカイブのCD-ROMが配布された。こ れを引き継ぐ形で、芦野俊宏現委員長がオ ンラインのアーカイブを完成された。学会 誌等が全巻揃い、カバーツーカバーで居な がらにして見られる電子図書館である。

以前、スキャン画像データはガサ張るの で、データベースにはコード化データが必 要で、また検索にはマークアップが必須な どと思い込んでいたのが、まさに隔世の感 である。

ここに、国沢、芦野両先生のこうした地 道な学会への貢献に改めて敬意を表して 結語とする次第である。 